\title{
EFFECTIVE STRATEGIES FOR TEACHING VOCABULARY TO YOUNG LEARNERS
}

\author{
Hendra Eka Putra \\ Program studi Pendidikan Bahasa Inggris Sekolah Tinggi Agama Islam Negeri Batusangkar \\ Korespondensi: Jl. Simpang Bendang No. 2 Tigo Tumpuak Lima Kaum Batusangkar \\ e-mail: hendra_kadam@yahoo.com
}

\begin{abstract}
Vocabulary learning is very necessary and an indispensable part of any language learning process. In the ESL context, vocabulary not only supports the four language skills; listening, speaking, reading, and writing, but also mediates between ESL students and content-area classes in that the students often find that lack of vocabulary knowledge is an obstacle to learning. This article focuses on and discusses effective strategies for teaching vocabulary to young learners which greatly assist English language learners in their journey of language acquisition and also expedite the language learning process
\end{abstract}

Kata kunci: effective strategies, vocabulary, young learners

\section{INTRODUCTION}

$\mathrm{V}$

ocabulary teaching and learning are constant challenges for teachers as well as learners because historically there has been minimal focus on vocabulary instructions in the ESL classroom. Due to this, an increased emphasis on vocabulary development is crucial for the English language learners in the process of language learning.

Since the focus of this article relies on the effective strategies for teaching vocabulary to young learners, it is crucial to highlight the importance of vocabulary instruction in the ESL classroom. Stahl in Taylor (1990) found that vocabulary instruction directly improves comprehension. $\mathrm{He}$ also declares that as the difficulty of words in a text increases, the understanding of the text decreases; therefore, it is critical for the learners to have a deep understand- ing of vocabulary in order to understand new concepts.

Furthermore, vocabulary is positively related to higher-status occupation (Marzano, 2004, as cited in Zwiers, 2008). It can be said that vocabulary acquisition is necessary to academic, social, and professional successes. The more diverse, creative and effective teaching strategies the teacher in the English classroom employs, the richer the students' language becomes and the more likely they will experience successes with the content and will be able to communicate with various registers.

Therefore, through this article the writer tries to give information about effective strategies for teaching vocabulary to young learners. It will also discuss how important vocabulary is and what the language learners should do to get many vocabularies in order to 
facilitate them communicate with the world.

\section{WHAT IS VOCABULARY?}

According to Hornby (1974: 959), vocabulary can be defined in three ways: total number of words (with rules for combining them) which make up language, range of words known to a person and containing a list of words with definition or translation. Similarly, Nunan (2003: 130-132) defines vocabulary in three ways: multi-word unit, word families and core meanings.

While, Gardener in Adger (2002) states that vocabulary is not only confined to the meaning of words but also includes how vocabulary in a language is structured. It means that it relates to how people use and store words and how they learn words and the relationship between words, phrases, categories of words and phrases.

Then, Cummin in Herrel (2004) states that there are different types of vocabulary. They are listening, speaking, reading, and writing vocabulary. Listening vocabulary refers to all the words an individual can recognize when listening to speech. Speaking vocabulary refers to all the words an individual can use in speech. While, reading vocabulary refers to all of the words an individual can recognize when reading a text. Then, writing vocabulary includes all the words an individual can employ in writing.

Consequently, vocabulary is positively related to lexicon which refers to a reference book containing an alphabetical list of words with information about them and can also refer to the mental faculty or power of vocal communication. It is supported by McCarthy in Taylor (1990) who states that the role that mental lexicon plays in speech perceptions and production is a major topic in the field of psycholinguistics and neurolinguistics.

\section{WHY LANGUAGE LEARNERS NEED VOCABULARY?}

Academic comprehension will improve if the learners know the meaning of words. Words are building blocks of communication. When the learners have a great vocabulary, they can improve all areas of communication, namely: listening, speaking, reading, and writing. When students have a higher academic vocabulary development, they can tolerate a small proportion of unknown words in a text without disruption of comprehension and can even infer the meaning of those words from rich contexts.

Besides, without some knowledge of vocabulary, neither language production nor language comprehension would be possible. It means that the growth of vocabulary knowledge is one of the essential pre-requisites for language acquisition and this growth of vocabulary knowledge can only be possible when teachers employ effective vocabulary teaching strategies which are the objectives of this article.

Green (2009:1) declares that there are some importances of vocabulary. First, vocabulary has become a powerful insight to raise achievement. To be successful in learning acquisition, the learners should have much vocabulary. Second, vocabulary plays importance role in the four English skills. In listening ability, it gives ease for the learners to comprehend what the other persons speak. In speaking and writing, it gives chance to the learners to expand their ideas. In reading, it also helps the learners to comprehend the text easily. Third, the creation of words is a tool for increasing learning. It means that vocabulary is very important to improve the four language skills: listening, 
speaking, reading, and writing. Fourth, vocabulary instruction is a vocal point of learning. It is supported by Lehr (2004: 1) who states that there is an urgency to provide instructions that equip learners with the skill and strategies that is necessary for lifelong vocabulary development. Thus, the teacher's approaches should be maximized in vocabulary learning in order to enrich the learners' achievement. At last, vocabulary instruction is not only as an excellent advance organizer but also must be taught in context. It means that the teacher cannot even begin to design techniques in the classroom without considering the contexts of learning.

\section{NATURE OF YOUNG LEARNERS}

According to McKay (2006: 1), young learners are children who are in primary and elementary school. This opinion is supported by Hoesein in Daristya (2008) who states that young learners are the students of elementary school who are at grade four up to grade six.

Then, Purwaningsih in Daristya (2008) states that young learners are the learners in elementary school of aging 910 years old who are learning English as a foreign language. It means that in terms of age, young learners are between the ages of approximately five and twelve.

\section{CHARACTERISTICS OF YOUNG LEARNER}

According to Harmer (2003: 38), there are some characteristics of young learner. First, the children respond to meaning even if they do not understand individual words. This means that they do not focus on the meaning of word per word, but they will catch the meaning of the whole sentence. Second, they often learn indirectly rather than directly. They will learn everything around them rather than only focusing on what are being taught. Third, their understanding is not only from explanation but also from what they see and hear. Supeniati (2007: 1) states that the children respond the language well through concrete things (visual) rather than abstract things. Fourth, they generally display an enthusiasm for learning and a curiosity about the world around them. Fifth, they have a need for individual attention and approval from the teacher. They need to understand what it means to learn, and they need a good attention from their teacher to make them more understand. Sixth, they are keen to talk about themselves and respond well to learn their own lives as main topics in the classroom. At last, they have limited attention span; unless activities are extremely engaging they can easily get bored, loosing interest after ten minutes or so.

Furthermore, Supeniati (2007: 1) states that young learners are children who will be enthusiastic if they are taught using fun activities or being involved in activities. It means that the learners will enjoy learning English if they are faced with fun condition which make them interested and enthusiastic.

In addition, Lafever (2007: 27) states that young learners at transition level (ages 5-8) generally have characteristics like keen and enthusiastic, curious and inquisitive, outspoken, imaginative and creative, active and like to move around, interested in exploration, learning by doing hands-on experience and holistic, and natural learners searching for meaningful messages. It means that they will learn well if they are involved in the process of learning. 


\section{INDICATORS OF A GOOD VOCABULARY MASTERY FOR YOUNG LEARNERS}

According to Sumarni (2008: 10), there are some indicators that learners can master vocabulary. They are as follows:

1. The learners are able to recognize vocabulary in its spoken and written forms.

2. The learners are able to recall it at will. When they need it, they can retrieve the vocabulary.

3. The learners are able to relate the vocabulary to the real object or concept.

4. The learners can spell the vocabulary correctly.

5. The learners are able to pronounce words, and they can use those words in good pronunciation.

6. The learners know in what ways it can combine with other words to be correct sentence.

\section{PRINCIPLES OF TEACHING VOCABULARY TO YOUNG LEARNERS}

Teaching English vocabulary to young learners can be started by introducing vocabulary to them. Teaching vocabulary to young learners should be interesting and fun in order to interest them to learn and improve their motivation in learning English, especially in mastering English vocabulary.

According to Nunan (2003: 135141), there is a set of guiding principles that can be applied in a variety of teaching and learning situations. They are focusing on the most useful vocabulary, focusing on the vocabulary in the most appropriate way, giving attention to the high frequency words across the four strands of a course, and encouraging learners to reflect on and taking responsibility for learning. Focusing on the most useful vocabulary means that some words can be used in a wide variety of circumstances. For example, the word help can be used to ask for help, to describe how people work with others, to describe how knowledge, tools, and to indicate material that can make people's work easier and so on.

Focusing on the vocabulary in the most appropriate way means the first principle looks at what words to teach and learn. This principle looks at how they should be taught and learned. Therefore, the teachers need to clearly differentiate the way they treat high frequency words from low frequency words clearly. While, giving attention to the high frequency words across the four strands of a course, high frequency vocabulary should get deliberate attention through teaching and study and should be met and used in communicating messages in listening, speaking, reading and writing.

Then, encouraging learners to reflect on and take responsibility for learning refers to the learners need to realize that they have to be responsible for their own learning. Taking this responsibility requires knowledge of what to learn and the range of options for learning vocabulary, skill in choosing the best options, and the ability to monitor and evaluate progress with those options.

In addition, Schmitt in Ikah (2006: 13-14) states some key principles of teaching vocabulary. They are building a large sight of vocabulary, integrating the new words with previous words, providing a number of encounters with a word, promoting deep level of processing, facilitating imagination, making new word 'real' by connecting them to the students' word in some way, using various strategies, and encouraging independent learning strategies.

Based on the theories, teacher should master those principles before 
applying teaching in the classroom. And, s/he has to use them based the students' need to the vocabulary in order to help them to communicate in real life communication both spoken and written form.

\section{EFFECTIVE STRATEGIES FOR TEACHING VOCABULARY TO YOUNG LEARNERS}

There many strategies can be used by a teacher in teaching vocabulary to young learners. Here, there writer will show some of the strategies proposed by some experts. Manandhar (2009: 1) states that there are some strategies of teaching vocabulary to young learners. They are as follows:

1. Using Realia

Realia refers to real objects or things. Generally, any objects of things can be carried out into school to represent the meaning.

2. Using Matchstick Figure

Matchstick figure is known as pinmen. It refers to simple sketch rather than a real picture drawn in fully artistic manner.

3. Using Picture

Picture relates to the object that cannot be brought easily into the classroom, so unavailable object in the locality can be represented by using picture.

4. Using Synonyms

Synonyms mean words that refer to more or less the same meaning of thing.

5. Using Antonyms

Antonyms refer to the opposite meaning of a specific object or thing. Mastering it will help learners to know new vocabulary.

6. Using Definition

Some words especially in advanced level can be taught by giving their meanings.
7. Using Demonstration

Demonstration refers to the actions done by a teacher.

8. Using Presenting Lexical Set/ Enumeration

Sets of related words can be presented to refer to the meaning of the cover term as well as to the words involved in the same group.

9. Using Games

Games help to avoid the monotous learning process. There are many games can be applied by a teacher such as cross word puzzle, guessing, and so on.

10. Using Audio/Visual

Many words can be more easily presented by a tape recording or video rather than the above mentioned ways.

Next, Nunan (2003: 141) states that there are four principle strategies that can be employed in teaching vocabulary. They are meaning focused input activities, deliberate learning activities, meaning focused on output activities, and fluency activities. Deliberate learning activities involve learning to use vocabulary learning strategies of word cards, guessing meaning from context, using word parts and dictionary use. A professional teacher may select one of them for their teaching target to promote the learners' successful in learning.

Furthermore, Herrel in Henriksen (1999) proposes several effective strategies for teaching vocabulary to young learners. They are in the following.

1. Guessing meaning from context

To employ this strategy, there are many strategies that can be applied by a teacher in a classroom, namely:

a. Definition

A definition gives the meaning of words. A writer may use phrases or statements to define something. The key words used to 
provide a definition are: "are/is knows as," "are/is described as," and "are/is defined as."

b. Restatement

The writer may use other words, phrases or sentences to provide meaning of difficult words. The key words used in restating something: "in other words", "that is", "that is to say," and so on.

c. Punctuation marks

The writer usually uses punctuation marks to describe the meaning of unfamiliar words. The writer will write unfamiliar words and then use punctuations, words, phrases or sentences to explain new words. Punctuation marks are-commas, "" inverted commas, ( ) parentheses, ; semicolon and: colon. For example, Family members (siblings) should always stick together.

d. Examples

Examples help learners to understand the meaning of new words. The key words are "such as," "like," "for example," "for instance," and "is/are" are used by an author.

e. Contrast

Contrast shows the opposite meaning of new words. The key words are such as "but," "instead of," "even though," "in contrast to," "yet," and "in spite of" are used by an author.

f. Similarity

The writer may also use signal words of similarity such as "like," "similarly," "in the same way," "as," and "just as".

g. Surrounding words

Words surrounding the new vocabulary might provide clues to the meaning of the new words. For example, "Children are too young to understand that swallowing gum can be dangerous".

h. Background Knowledge

Experience and background knowledge about the text plays an important role in vocabulary comprehension. For that reason, it is important for teachers to do schema-building before learners read a text.

2. Teaching collocations

Vocabulary knowledge does not involve just knowing the meaning of a word in isolation, but includes knowing the word that usually cooccurs with it. These words that cooccur with high frequency are called collocation, e.g. heavy rain, strong coffee but not powerful coffee, a brief discussion but a short man. Collocations help learners to define the semantic area of a word such antonym, synonym, hyponym, and word formation.

3. Teaching word family

Development in lexical semantics and the mental lexicon have prompted the development of semantic field theory, semantic networks or semantic grid strategies which present and organize words in term of interrelated lexical meanings. A simple example of a semantic field is the set of kinship term such as father, mother, brother, sister, son, daughter, uncle, and aunt or the various body parts learned as a subset.

4. Recycling content

It means that if the learners are actively involved in processing the lexical item (intentional meaning), they are likely to remember it. It is therefore the teachers' responsibility to create meaningful contexts in which learners have the opportunity to recycle and reuse the vocabulary they have learned. 
5. Keeping a vocabulary journal It is important for language learners to record the words they learn or encounter. Vocabulary journals can serve as a reference source in and out of the class. Once learners record the target vocabulary, it becomes easy for them to remember or use it.

6. Eliciting

Through this, the learners can call out or write the target word. This can be in the form of definition, antonyms or synonyms. This activity enables the learners to express meaning and explore knowledge of the target vocabulary deeply.

7. Contextualization

The learners can learn to use the word in sentences through gap filling activity, story-building or roleplaying activity.

8. Labeling

Here, the learners can label various parts or objects in class. This activity can be extended at home or immediate environment.

9. Personalization

This process is also known as deepprocessing. The learners can visualize themselves doing a specific activity relating to the target vocabulary, e.g. Learners imagine themselves rowing a boat. So, the target vocabulary is the word 'row'.

10. Learning vocabulary by identifying productive pre-fixes and post-fixes

Learning the most common productive pre-fixes and post-fixes can enable learners to understand a thousand other academic words, which use one or more of those word parts. Word part clues are highly memorable because they are simple to understand, e.g. the word $b i$ means 2 and anti means against.

11. Association

Learners can learn to associate the new vocabulary or target word with something they already know or something that is meaningful to them.

12. Semantic mapping

This strategy can be used to motivate and involve students in thinking, reading and writing. It enhances vocabulary development by helping them to link new information with previous experience. This is done by making an arrangement of words in a picture, which has a key concept at the centre and related words and concepts linked with it.

13. Categorizing words

It can be done by asking the learners to categorize words. Categories can include action verb-to run, run on gasoline; nouns-knight, night; auxiliary verb-will- future tense, a will, be, bee; adjectives-round, round of applause; and prepositions-in, to, two, too.

\section{CONCLUSION AND SUGGESTION}

\section{Conclusion}

Based on the discussion above, those effective strategies will provide the teachers to use one of possible strategies in their teaching. The teacher can use them in order to help or guide the learners to have much vocabulary. Having much vocabulary will help the learners to participate in all classroom activities that need English.

\section{Suggestion}

Since the goal of teaching vocabulary to young learners is to mediate the learners to have much vocabulary, it is important to the teachers to select effective strategies in their teaching activities. Due to this way, the successful of strategy choice to be used will influence their success in teaching. 


\section{BIBLIOGRAPHY}

Adger, C.T. What Teachers Need to Know about Language. London: Merril Publising Company. 2002.

Daristya. Teaching English for Young Learners. Available in http://sirogoal.blogspot.com/2008/ 12/teaching-english-for-young learners.html. Retrieved on 07 January 2012. 2008.

Green. The Importance of Vocabulary. Available in http://www.greenville.k12.sc.us/le ague/libweb/teachers_files/importa nc.doc. Retrieved on 07 January 2012. 2009.

Harmer, Jeremy. The Practice of English Language Teaching. New York: Longnman. 2003.

Henrikson. Three Dimensions of Vocabulary Development. Cambridge: Cambridge University Press. 1999.

Herrel, A.L. Fifty Strategies for Teaching English Language Learners. Cambridge: Cambridge University Press. 2004.

Hornby, AS. Oxford Advanced Learner's Dictionary of Current English. Oxford: Oxford University Press. 1974.

Lehr, Fran. A Focus on Vocabulary is the Second Research-Based Practices. Available in http://www.prel.org/products/re_/E S0419.htm. Retrieved on 07 January 2012. 2004.

Latever, Samuel. English for Young Learners. Available in http://malfridur.ismentnt.is/haust20 Indeks

effective, 37, 182, 185, 187, 188 06/pdf/malfr_27-31.pdf. Retrieved on 04 January 2012. 2007.

Manandhar, Sunita. Ways of Teaching Vocabularies to Beginners. Available in http://symmaruna.wordpress.com/2 009/08/18/ways-of-teachingvocabularies-to-beginners/.

Retrieved on 07 January 2012. 2009

McKay, Penny. Assessing Young Language Learners. Cambridge: Cambridge University Press. 2006.

Nunan, David. Practical English Language Teaching. New York: McGraw Hill Company. 2003.

Santa. Teaching Vocabulary through Word Box Technique. Available in http://www.itrc.ucf/fordp/strategies /start.Map.html. Retrieved on 09 January 2012. 2004.

Sumarni, Retno. Increasing Students' Vocabulary Mastery Using Realia at the Fifth Year of SDN 1 Blimbing Ampelgading Pemalang. (Unpublished Thesis). Malang: Universitas Negeri Malang.

Supeniati. Young Learner Characteristics. Available in http://peni.staff.uns.ac.id/2008/10/ 10/young-learner-characteristics/. Retrieved on 07 January 2012. 2007.

Taylor, L. Teaching and Learning Vocabulary. UK: Prentice Hall Regent. 1990.

Zwiers, J. Building Academic Language. London: Newark International Reading Association. 2008.

strategies, 37, 182, 183, 185, 186, 187, 188 